\title{
START-UP FOR SUSTAINABLE GROWTH IN BULGARIA
}

\author{
D. Blagoev, D. Kopeva, N. Sterev*, Z. Jordanova, V. Bojilova \\ Business Faculty, University of National and World Economy, Sofia, Bulgaria
}

\begin{abstract}
The new-thinking is growing up as a contemporary entrepreneurial concept. So, the new-business establishment has been changed a lot of after the Schumpeterian entrepreneur has been set.

The business proof of this newer type of entrepreneurs is the phenomenon "START-UP" - a new business with high growth potential. The social-economy proof of "Startup" concept is the development of EU policies and strategies that include instruments concerned of this type of new-born business.

According to the above, the paper is structured as follows: Introduction: the basic research thesis is given, 1. State of art: defining the problem. Summary of the most used definition of "Start Up" and "new high potential business" are given in this paragraph; 2.Effects of start-ups: some figures from the good World and EU practices. Some positive impacts on the economic growth are represented, explained and discussed; Conclusions: summary of the knowledge of Start-Up impact on growth is given.
\end{abstract}

Key words: start-up, entrepreneurship concept, sustainable growth

\section{INTRODUCTION}

In recent years, more and more papers have discussed the need to establish and develop a new business (resp. companies, enterprises) that possesses a potential for accelerated growth. The basic needs for such a new-type of business could be summarized as follows:

- The modern economy, especially after 2008, needs a larger number of innovative practical implemented business ideas to ensure and provide "normal" and expected growth of the national and global economy.

- The distinction of "entrepreneurial based business" between those with limited, respectively small potential and those with high growth potential requires introducing of appropriate concepts.

- Policy targeting, strategies and measures at national, European or global level to the most promising business ideas, is also a prerequisite different entrepreneurial business initiative should be distinguished.

In search of a suitable concept for Start Up Business we had to set the following limitation: formation of separate group of START-UPS in no way contradicts the Schumpeterian entrepreneurial theory.

* Correspondence to: Nikolay Sterev, Business Faculty, UNWE-Sofia, tel: +35928195 411, email: sterew@abv.bg
Although for the past 50 years the establishment of new, mostly small, small or medium business, significantly differ from the conceptual framework of Joseph Schumpeter stating that the developer, carrier of the innovation, is the driving force of the modern economy open market type.

The above thesis is used as the main argument for the European Commission to introduce a "new" concept of "small and medium enterprise" in 2003 by Commission decision 2003/361 / EC, published in the EU Official Journal in the issue L 124, p. 36 of May 20, 2003 which in 2005 was renewed in terms of quantitative parameters for the number of employees, turnover and net book value of fixed assets.

\section{STATE OF ART}

\subsection{Concept and evolution of START UP Business}

The rapid expansion of companies operating on the internet as well as the speed by which some of them developed (known as "dot com .com" companies) allow to define as a START UP company with high growth potential the following business:

This is a new business entity, association or temporary business organization whose main purpose is seeking of business decision on 
repetitive, cyclical problem, through innovative methods and tools.

This definition implies that the Start Up Business is determined only as initiative entrepreneurial business at an early stage of development and the developer/ $\mathrm{s}$ creates specific business organization structure to ensure financing and realization of the original innovative entrepreneurial idea. This implies that an undertaking (either left to exist as a small or medium, or has evolved to big business) idea at a time to be defined as starting company with high growth potential (resp. Start Up Business). This moment occurs when:

- Entrepreneurial business idea fails, either the business continues to exist or to occur termination, bankruptcy entrepreneurial organization structure.

- Entrepreneurial business idea and development itself becomes an attractive target for merger or acquisition with other business companies (agents).

But the first step identifying the Start Up business idea is to fill the following checklist (Table 1)

Table 1. Checklist of Start Up Business ideas

\begin{tabular}{|c|c|}
\hline Possibility & Where does the business idea come from? \\
\hline Innovation & What's the innovative aspect of the business idea? \\
\hline Customers & Who is the client? \\
\hline Competition & Who is the market opponent - rival? \\
\hline Sales & Through which sales channel can reach the customer? \\
\hline Marketing & How to create and use consumer demand in the market? \\
\hline \multicolumn{2}{|c|}{$\begin{array}{l}\text { What makes the business development of the Transactions? Partnerships? Sales? } \\
\text { idea? }\end{array}$} \\
\hline Nature of the business model for profit & What can be done to earn money in December? \\
\hline Intellectual property / acquisition of patents & Is there any and how long can be held? \\
\hline Time to market & What time does it take to come up in the market? \\
\hline Model of Product Development & How the engineers can ensure the development of the idea? \\
\hline Production & What is the cost for producing the product? \\
\hline Initially targeted funding & How much? When? \\
\hline Subsequent funding & How much? When? \\
\hline Liquidity & How much? When? \\
\hline
\end{tabular}

Start Up companies can be at any legal form and size of business, respectively micro, small, medium or large business. A major task in establishing a business is to conduct research in order to validate the assessment of development of business ideas or concepts in addition to opportunities to create further and deeper understanding of business concepts or ideas and their commercial potential. A company may cease to be bootable as it passes various stages, becomes a publicly traded or cease to exist as an independent business unit through merger or acquisition. Companies can also fail and fully cease to function.

Investors are generally most attracted to those new companies that are characterized by high risk and therefore returns. This is why they often have lower costs for starting higher risk and thus higher potential for return on investment. Successful Start Up companies are usually quoted by established business. In the sense that they have the potential to grow quickly with limited investment capital and sometimes labour.

\subsection{Newcomer START UP vs. existing business}

Newcomers in business presented as newly installed as an opponent of already established company in the market. This opposition seems destined: existing business has an advantage in view of his knowledge of customer marketing. However, they can identify several facts that give advantages of Start Up Business:

1. The existing business is known, notorious for his goals, strategies and policies. From this perspective, the new START UP is the unknown idea - which makes it extremely quiet and invisible opponent. Undoubtedly, very rarely an established company retains its market position in the emergence of successful Start Up Business idea. In summary, for existing companies failure would be painful and for newcomer companies - success would be painful.

2. Start Up Business focuses on the medium of the new idea and do everything possible to realize it. It delivers extra added value for the user. Contrary to them, existing companies are focused on their existence: end revenue financial results and growth potential. This makes them less responsive to changes in values and attitudes of consumers. 
In summary, the new Start Up Business ALWAYS wins against the established business. Failure of the entrepreneurial idea is an expression of lack of Start Up business idea in the creation of new business.

\section{EFFECTS OF START-UPS}

The Start Up business is part of the national economic system and it participates and contributes to economic growth. Recently we found an increase of their importance to the economy as they enlarge their share in the economic growth and gross domestic product. This is conditioned by the fact that the specificity of Start Up companies, in their genesis suggests they produce innovative and in most cases high-technology products and services with high added value, which in turn leads to growth in gross domestic product.

\subsection{Industrial Dynamics and START -Ups}

Analysis on dynamics is an analysis on the development of industries, changes in the content, limits their shares in the overall economy. Therefore dynamics is the movement of the boundaries of various industrial categories.

Undoubtedly the strong fluctuations in dynamics derived from the establishment of new industries, new markets, the creation / provoking new needs, covering a large proportion of the population (users) or from the innovation. As a collective phenomenon, innovation is considered the most powerful generator of new markets and form new needs. Innovations can cause tangible changes in dynamics through targeted activities to improve the current goods or more effectively to meet the needs and even to create new ones. Therefore, it should be noted that not all innovation or Start Up's product could affect dynamics a many of as the innovations carried out by innovative companies whose main activity is the development innovation. Many innovations replace similar products that reduce its share in the product portfolio of the company and the industry and the real change/growth is not happening. This is a result of specialization of most businesses and respectively a result of focusing their efforts in a particular area. For these reasons it can be summed up that the impact on industrial dynamics are primarily new companies generate innovations or companies that implement technology transfer between different categories of industries.

Nevertheless, to analyse industrial dynamics we should pay attention to Start Up companies. They are newly established companies and always in their activities is embedded innovation. In this side, the development and implementation of innovation suggest rapid growth, which could affect the boundaries of the sector, and investment in this kind of companies require fast and high profit rate and return on investment. As such, Start Up companies have all the characteristics to be among the main subjects affecting industrial dynamics.

Their impact on industrial dynamics is mediated by the strong deindustrialization in recent years and cessation activities of large companies in the mining, metals, machinery and others. Processes that form the industrial dynamics are different and result in changes in the industrial structure. This is further strengthened by reducing the share of large (privatized) enterprises and industries which previously accounted for a large share in the overall industrial structure and provide a relatively stable dynamics. These two interdependent processes (deindustrialization and increasing importance of Start Up companies) are caused by naturally transition from industrial society to an information society. In this part of the study will clarify the relationship of Start Up companies and industrial dynamics. Analyses of industrial dynamics often act as a source of valuable information on how to challenge the economic growth sectors that need investment, budget support, upgrading technologies and others.

\subsection{Economic growth and Start Ups}

Economic growth has to estimate the increase in manufactured goods by economic operators. In this role, Start Up companies represented entities that directly affect the cost of economic growth.

In recent years, Bulgaria has made small but steady growth. For 2013 the results were even higher than expected. These better results come from revisions in the data, especially the stronger growth in investments last quarter.

\section{Why Start Up companies really have a direct and directly related to economic growth?}

This is due to the nature of Start Up companies as companies that represent a high risk profile, chasing rapid initial growth of profit and quick return on investment. The growth rate, which defines them as Start Up companies, and expectations of a quick return on the initial investment gives this type of companies primordial objective for quick profit is not you achieve the planned short timeframe, the company was restructured. The goal of the investor is repeated increase in profit in the first months / years of activity and 
return on investment within 2-3 years from the start of operations.

\section{How this affects the aggregate economic growth?}

We found that its wave influences on economic growth, depending on concentration of Start Up companies, their internal dynamics and timing, their performance and others. At high concentration of Start Up companies which can be expected rapid growth - the aggregate economic growth of the country would be affected rapidly and immediately. This is why the time range of the rapid growth in revenue, which is embodied the essence of Start Up companies. Start Up companies are the fastest possible way to influence the national economic growth. In all other business activities, expected return periods are much longer, the profit margin is lower because of the long term objectives of the companies and the stability we seek to build. High risk profile of the Start Up companies turning them into companies seeking higher margin and faster results. In absence of a such quick results, returns and profit margins usually choose fast closing of positions with minimal losses, meaning the sale of the assets acquired (again quickly to use the funds in a new business venture).

Several years after the global financial and economic crisis that froze plans of many startups, reduce opportunities for corporate lending by the banking sector and increase the risk requirements of investors, business once again demonstrated willingness to create a Start Up companies. This is clearly illustrated by statistics measuring the dynamics of Start Up companies venturing on the information that in 2013 worldwide based over 140,000 Start Up companies [10] ${ }^{1}$.

When we talk about economic growth, it must first be shown the influence of the particular subject on the economy. Often in the activities of Start Up companies are formed accelerators or incubators for their seamless and rapid development. These accelerators can be a result of state support, regional policy or collaborative private interest. In their activities include mentoring, specific training to develop scientific activities, financing and more. Against the assistance provided to Start Up

\footnotetext{
${ }^{1}$ In Bulgaria have been established two accelerators that have gained prominence as venture capital funds. This is Eleven ( http://eleven.bg/bulgarian/ ) and LAUNCHub ( http://launchub.com/ ). There have not yet established a specialized business incubators for Start Ups, as part of the environment for innovation, stimulate and support the activities of this type of companies
}

companies, accelerator gets stake in the company.

Start Up companies are a tool for attracting foreign capital, which in itself is a factor for economic growth and changes in industrial dynamics.

\subsection{Role and impact of START UPs on the national economy}

There are examples that show how entrepreneurship causes the generation of new ideas on local and regional level through the "contagion effect". So if some entrepreneur or establishers of new companies succeed in realizing their ideas, then they can generate new ideas and invest money that have already earned. If this phenomenon occurs on one area at the same time, the serial entrepreneurship is spreading rapidly among the population and the generation of ideas and the establishment of new businesses that implement them rose sharply. In these cases, business with high growth potential, called them Start Up companies, affected very much on the regional economy, while relative success and duration of the phenomenon - have a major impact on the national economy and economic growth.

In any case, such situations have an abrupt change in industrial dynamics, as well as territorial and national level. One of the most famous examples is the Silicon Valley, whose contribution to the US economy is enormous, apart from the contribution of industry and technological development and undoubtedly the dominant influence territorially in direction: education, entrepreneurship, labour and others. Among the best-known companies operating in this artificially separate territorial administrative unit, but are very important for business development and technology are Google, Apple, Facebook, Twitter, Quora, AirBnb. The existence of the Silicon Valley phenomenon has given inspiration to many other countries and cities to try to build similar business systems -oriented innovation, technology, the new companies. This is usually achieved through government policy, identification of priority sectors to be budget stimulated accumulation of scientific and entrepreneurial capacity in one place and others. Among the most famous and productive Start Up business systems are: Tel Aviv, Los Angeles, Boston, New York, Seattle, Vancouver, Toronto, London, Chicago, Singapore, San Paolo and others [8]. There are over 105 separate ecosystems that are built in particular the example of Silicon Valley in 79 locations around the world including India, Australia, Zanzibar, other states of the US, Japan and others [16]. 


\section{CONCLUSIONS}

The main factors that prevent organizations to develop innovative policy and resp. their leaders to apply innovative principles and practices in their management, are as the next: already established structures, procedures, personnel and operating principles. All those already existing business ideas are not easy to be adapted or modified to new objectives and innovation needs of innovation management. In addition, its often situation that existing structures, resources, personnel, procedures and principles are limiting factor even for the formation of ideas. Even though, undergone initial barriers innovative ideas fall by the selective procedure due to higher expenses in the additional difficulties caused by changes in business organization.

Contrary, innovation leaders are difficult to apply the principles of innovative thinking in the already established organization without being implemented major changes in the structure to be adequate training and resources available. Even through the implementation of innovation culture in an organization, hard may create favourable conditions for the creation of innovations of all types.

All these constraints are missing in the new companies based on specific innovative idea, such as Start Up companies. They not only need modifying, but the structuring of resources possible to follow the current needs of innovation.

\section{So, Why innovative leadership is especially} important for the Start Up companies?

Start Ups are established by innovators as generators of ideas and innovations that have the ability to combine the following basic skills are the same for manager Start Up Company and innovative leader:

- To generate ideas or motivate others to generate ideas that result in innovation;

- To gather a team for the purpose of carrying out an innovative project;

- To seek the necessary resources for innovative projects;

- To exploit new and modern approaches to expose or create client needs.

The role of innovative leadership in the Start Up companies is extremely high. In this sense, the START UP leaders cannot rely so much on their entrepreneurial (business) thinking and to base their decisions on experience and established business practices. They should rely heavily on intuition and experiment inherent principles of innovative thinking leadership.

Implementation of innovative thinking $[1 ; 3]$, innovative approaches and methodologies in the founding and management of Start Up companies is a "good practice" that is still not common used. So, there is a need of more papers that explore the positive effects of Start Up business to the growth and development.

\section{REFERENCES}

1. Aslanova, L., Leadership and Innovation, innovationstarterbox.bg/liderstvo-iinovacii/, 2014

2. Barsh, J., Capozzi, M., Davidson, J., Mckensey Consulting Company, Leadership and innovation, 2008, accessed on: www.mckinsey.com

3. Blanc, S., Why the Lean Start-Up Changes Everything, Harvard Business Review, 05.2013, access on: https://hbr.org/2013/

4. Baumgartner, J., The Way of The Master Innovation, accessed on: www.jpb.com/books/index.php

5. Deschamps, J., Innovation leadership in practice, accessed on: http://up-grade.me

6. Kenny C. and D.Williams, 2001, What Do We Know about Economic Growth? Or Why We Do not Know Very Much? World Development, 29: 1, 1-22

7. Schoof U., Stimulating Youth Entrepreneurship: Barriers and incentives to Enterprise Start-UPS by young People, available on-Line on: http://www.ilo.org/youthmakingithappen/P DF/WP76-2006-Rev.pdf

8. Startup Genome, Telefonica, Digital, Startup ecosystem report, 2012

9. The new SME definition: User guide and model declaration, 2003, ec.europa.eu/enterprise/policies/sme/files/s me_definition/sme_user_guide_en.pdf 2014.startup.bg/

10.Startup World Report, available on-Line on http://www.worldstartupreport.com/

11.www.businessdictionary.com

12.www.entrepreneur.bg/6737/shest-faktakoito-da-vzemem-predvid-izgrazhdaykiekipa-na-svoya-startap/

13.www.Flashpoint.com

14. www.investor.bg/mneniia-isyveti/129/a/startirashtite-firmi-chestopropuskat-prouchvaneto-na-klientite-si181692/

15.www.investor.bg/novini/261/a/sedemgrycki-start-ypa-koito-zaslujavat-vnimanie164779/

16.www.tbtf.com/siliconia.html

17.www.thebalancedentrepreneur.com/Startup _Perform_a_SWOT_analysis 
BLAGOEV D., et al.

Trakia Journal of Sciences, Vol. 13, Suppl. 1, 2015 